\title{
Comparison of Response to Nitrogen between Upland NERICAs and ITA (Oryza sativa) Rice Varieties
}

\author{
Geoffrey Onaga \\ Department of Crop Sciences, University of Göttingen, Grisebachstrasse 6, 37077 Göttingen, Germany \\ E-mail: onafrey@yahoo.com
}

Godfrey Asea

National Crops Resources Research Institute (NaCRRI), Namulonge P.O Box 7084, Kampala, Uganda

E-mail: grasea_99@yahoo.com

Jimmy Lamo

National Crops Resources Research Institute (NaCRRI), Namulonge P.O Box 7084, Kampala, Uganda

E-mail:1amojim@gmail.com

Joseph Kikafunda

National Crops Resources Research Institute (NaCRRI), Namulonge P.O Box 7084, Kampala, Uganda

E-mail: josephkikafunda@yahoo.com

George Bigirwa

Alliance for a Green Revolution in Africa, Eden Square, P.O. Box 66773 Westlands 00800 Nairobi, Kenya

E-mail: gbigirwa@agra-alliance.org

Received: December 31, 2011 Accepted: January 19, 2012 Online Published: April 26, 2012

doi:10.5539/jas.v4n6p197

URL: http://dx.doi.org/10.5539/jas.v4n6p197

\begin{abstract}
Average yields of upland rice are the lowest in Uganda, and most of the productivity gains attributed to improved varieties are related to increased area of production from clearing virgin lands for rice production. In a bid to optimize productivity, we compared the effect of four nitrogen fertilizer treatments: $0,40,80$ and 120 $\mathrm{kgN} / \mathrm{ha}$ and two variety types (ITAs (Oryza sativa) and NERICAs (New rice for Africa)) on grain yield and yield parameters in four locations. Combined analysis of variance revealed that nitrogen fertilizer increased mean grain yields from $2116-5200 \mathrm{~kg} / \mathrm{ha}$ in the NERICAs and $2331-5100 \mathrm{~kg} / \mathrm{ha}$ in the ITAs. In all the study areas, NERICA 4 and NARIC 2 outperformed NARIC 1 and NERICA 1, and yield trends were consistent over the years suggesting that the two varieties respond better to $\mathrm{N}$ fertilizer application. However, the productivity gains are probably related to genetic potential of the varieties rather than the $\mathrm{N}$ fertilizer effect, as reflected by the consistent relative performance between $0 \mathrm{~N}$ and other $\mathrm{N}$ rates. The heavier grains of NARIC 2 and NERICA 4 suggest greater dry matter accumulation before heading, as these varieties have a longer period of vegetative growth. The significant interaction of location $\mathrm{x}$ fertilizer and location $\mathrm{x}$ variety reveals the need for evaluating the nitrogen-supplying power of soils in the various cropping systems in the country.
\end{abstract}

Keywords: ITAs, NERICA, Nitrogen fertilizer, Upland rice, Grain yield

\section{Introduction}

The popularity of upland rice in Uganda is fairly recent, and it is attributed to; a high rate of investment (1.8) among cereal crops (Kijima et al., 2006), increased promotion by stakeholders, availability of improved rice varieties and increased demand and consumption, particularly, among the urban population and neighboring 
countries. However, the average yields are around $1.5 \mathrm{t} / \mathrm{ha}$ as opposed to $3.5 \mathrm{t} / \mathrm{ha}$ under irrigated conditions (Ogenga-Latigo, 1995; Odogola et al., 2006). The low yields are largely a consequence of drought, low soil fertility (Briggs and Twomlow, 2002) and untimely weed management practices. In the last decade, the National Agricultural Research Organization (NARO) released four upland rice varieties (NARIC 1, NARIC 2, NERICA 4 and NERICA 1) with a potential to produce more than 4 t/ha. NERICAs (New Rice for Africa) are interspecific hybrids between the cultivated rice species Oryza sativa and O. glaberrima (Jones et al., 1997) while NARIC 1 and NARIC 2 are Oryza sativa types designated as ITA 257 and ITA 325. These cultivars have rapidly spread in the country due to a high demand and higher yields relative to the traditional varieties. Like any rice cultivar, these varieties require fertile soil for high productivity. However, fertilizer use is a rare practice among the rural poor, and most of the productivity gains attributed to these varieties are related to clearing virgin lands for rice production. This is coupled with the absence of updated fertilizer recommendation rates for newer upland rice varieties in Uganda. Nitrogen is the most limiting crop nutrient in upland ecologies (Koutroubas and Ntanos, 2004) and its availability for plant growth is largely influenced by soil heterogeneity (Clark et al., 2005, Boling et al., 2008). Efficiency of nitrogen use is also variable among rice genotypes (Sheehya et al., 1998; Zhou and Wang, 2003; Wang et al., 2005; Saito et al., 2006). However, when N-fertilizer is applied in the proper amount and at the correct time, N-fertilizer recovery up to $50-70 \%$ of total nitrogen applied can be achieved (Peng et al., 1996; Peng and Cassman, 1998; Wang et al., 2001; Ligeng et al., 2004). Increased uptake of nitrogen influences the number of tillers, panicles and spikelets produced per square meter (Yoshida et al., 1972), although with very high doses these increments are not significant. Where high doses of nitrogen are applied, there is an increase in the percentage of unfilled grains, some varieties being more sensitive than others in this respect (Hasegawa et al., 1994; Horie et al., 1997). Grain yield of rice is a combination of different yield components, such as the number of panicles per unit land area, the number of spikelets per panicle, the percentage of filled spikelets and the grain weight (Yoshida, 1983). The relative importance of each component varies with the location, cropping season, soil fertility, crop duration and cultural system (Koutroubas and Ntanos, 2004). The yield target for a given location and season is the estimated grain yields attainable with farmers' crop management when the constraints of N, P and K are overcome (Dobermann et al., 2004). In Japan, two upland NERICAs (NERICA 1 and NERICA 5) exhibited superior biomass production and yield under rainfed upland conditions as compared with selected Japanese rice cultivars (Matsunami et al., 2009). NERICAs were capable of absorbing greater amounts of $\mathrm{N}$ than the Japanese cultivars, a trait which, probably, contributed to the greater biomass production and grain formation, resulting in their higher grain yield. However, the NERICAs released for cultivation in Uganda have never been compared with other improved cultivars in response to nitrogen fertilizers. This study was designed to determine yield changes due to nitrogen levels and the influence of these on the yield components of the Oryza sativas and NERICA ecotypes.

\section{Materials and Methods}

Field experiments were conducted in 3 locations in Uganda: Iganga (Eastern), Masindi (Mid-Western) and Luweero (Central) during the year 2008 and 2009. All the experimental sites were typically upland rice production areas. One reference trial was established at the National Crops Resources Research Institute (NaCRRI), Namulonge. In all the locations, soil samples were collected from the trial plots before applying fertilizers and the samples were analyzed for soil nutrient status. The soil properties are briefly described in Table 1. The experiment involved four released popular varieties, NARIC 1 (ITA 257), NARIC 2 (ITA 325), NERICA 4 and NERICA 1. Nitrogen fertilizer was applied in form of soluble urea at four nitrogen rates: $0 \mathrm{kgN}$, $40 \mathrm{kgN}, 80 \mathrm{kgN}$ and $120 \mathrm{kgN} / \mathrm{ha}$ in split doses at 21 (tiller initiation stage) and 49 (active tillering stage) days after emergence. A basal application of $20 \mathrm{kgP}_{2} \mathrm{O}_{5} /$ ha in form of triple super phosphate and $20 \mathrm{kgK}_{2} \mathrm{O} / \mathrm{ha}$ in form of Muriate of potash was done just before seeding to ensure that $\mathrm{P}$ and $\mathrm{K}$ were not limiting. The experiments were conducted in a split plot design, with nitrogen rates as main plots and varieties as sub plots. Three replications were established per location. Seeds were drill planted in furrows spaced at $30 \mathrm{~cm}$ apart in randomized plots of $1.8 \times 5 \mathrm{~m}$ size. Six rows were planted to each variety per plot and all plots received identical cultural treatments in terms of cultivation, seed rate $(60 \mathrm{~kg} / \mathrm{ha})$ and pest management. Two middle rows in each plot were selected, and one meter from either side was randomly selected for recording plant height, tillers $/ \mathrm{m}^{2}$ and panicles $/ \mathrm{m}^{2}$. At maturity, panicles were harvested from either side of the tagged row plants and data on grain number per panicle was recorded. Grain yield, ripening ratio and 1000 grain weight were recorded from the harvest obtained from the selected four middle rows and the yield was expressed as $\mathrm{kg} / \mathrm{ha}$. The data was analyzed statistically with Fishers' analysis of variance technique at 5\% probability level, combined over the years. LSD values were calculated and used to compare treatment means. Simple correlation coefficients were calculated based on treatment means. 


\section{Results}

\subsection{Site Soil Analysis}

Analysis of soil samples from experimental sites revealed variability in nutrient and organic matter content (Table 1). Available $\mathrm{N}$ content was highest in Masindi followed by Namulonge. Lowest $\mathrm{N}$ content was recorded in Luweero and Iganga. Organic matter content was above the minimum requirement $(>2 \%)$ in all the locations where the experiments were conducted. The $\mathrm{P}$ values recorded in the experimental sites were well above the critical soil levels (Mehlich-1 $\mathrm{P}<5-7 \mathrm{mg} \mathrm{kg}^{-1} \mathrm{P}$ ) for occurrence of $\mathrm{P}$ deficiency in uplands (Dobermann and Fairhurst, 2000). Potassium content was also above the critical deficiency $(<0.2 \mathrm{me} / 100 \mathrm{~g})$ limits in all the locations. This suggests that nitrogen was the most limiting nutrient in all the locations.

\subsection{Response of Varieties across Locations}

Combined analysis of variance for grain yield and yield components are shown in Table 2. Consecutive increase in $\mathrm{N}$ level significantly increased grain yield of all the rice varieties in all the locations with the highest grain yield obtained at $120 \mathrm{kgN} \mathrm{ha}^{-1}$. Within each treatment, variety ranking in dry weight was similar to that for grain yield, and the results for the two years were consistent. For the location main effect, the highest grain yields occurred in Masindi and the lowest yields in Iganga (Table 3). A similar pattern of $\mathrm{N}$ response was observed when combined analysis over locations and nitrogen fertilization was performed (Table 4). Relative grain yield increment as a function of nitrogen fertilizer application in two years in four locations is shown in Figures 1-4. Yield curves generally show an upward trend except in Masindi where there was a decreasing trend. Means from the two highest treatments $\left(80\right.$ and $\left.120 \mathrm{kgN} \mathrm{ha}^{-1}\right)$ did not significantly differ from each other in Masindi and Luweero, but were distinct from the lower $\mathrm{N}$ treatments. The difference in yield response between the 2008 and 2009 seasons was apparent. Grain yields in 2009 were lower than in 2008 by about 12.4\%, averaged across all varieties and fertilizer rates. In general, nitrogen fertilizer application increased grain yield by $46.7 \%$ in Namulonge, $56.7 \%$ in Luweero, $50.7 \%$ in Iganga and $46.8 \%$ in Masindi. There was significant effect of location, cropping seasons, variety and their interactions on performance.

\subsection{Grain Yield and Yield Component Response to N Application}

With the exception of NARIC 2, NERICA 4 produced significantly the highest grain yield than other cultivars at $120 \mathrm{kgN} / \mathrm{ha}$ in all the locations (Table 6). However, percentage increase in grain yield due to nitrogen was larger for NERICA $1(52.7 \%)$ than for NERICA 4 (49.8\%), NARIC $2(49.3 \%)$ and NARIC 1 (49.3\%). Plotting the yield performance of the four cultivars against their mean yield in the 16 environments (4 fertilizer rates and 4 locations) showed insignificant difference among the cultivars in regard to nitrogen response (Figure 5). However, significant differences were recorded in tiller and panicle production, and 1000 grain weight. NARIC 2 and NERICA 4 produced significantly higher number of tillers and panicles than NARIC 1 and NERICA 1. Application of $120 \mathrm{kgN} / \mathrm{ha}$ increased panicle number by $31.7 \%$ in NERICA $1,30.6 \%$ in NERICA 4, 29.2\% in NARIC 2 and $30.6 \%$ in NARIC 1 . Tiller number increased by $48.0 \%$ in NERICA $1,41.2 \%$ in NERICA 4, 41.4\% in NARIC 2 and $46.8 \%$ in NARIC 1.

The number of spikelets per square meter (spikelet density) was significantly greater at $120 \mathrm{kgN} / \mathrm{ha}$, and was one of the major contributors to the increased grain yield. Mean grains per panicle increased by $23.2 \%$ (averaged over locations and fertilizer levels), with the highest number obtained in NERICA 4 (113.1) followed by NARIC 2 (109.3). The 1000 grain weight was also significantly higher in NARIC 2 and NERICA 4 at $120 \mathrm{kgN} / \mathrm{ha}$. The interaction pattern for 1000 grain weight was similar to that of the grain yield. The grain filling (ripening) ratio was not significantly different among varieties but there was a significant fertilizer $\mathrm{x}$ location and fertilizer $\mathrm{x}$ variety interactions in this aspect. Generally, the relationship in terms of response pattern between NARICs and NERICAs was relatively similar in all the traits measured.

\section{Discussion}

The two year experiments showed that nitrogen fertilizer application significantly increased rice yield, as has been reported previously (Yoshida, 1983; Pinheiro and de Castro, 2000; Wang et al., 2002; Saito et al., 2006; Haefele et al., 2008). The mean grain yields increased from $2411 \mathrm{~kg} / \mathrm{ha}$ with $0 \mathrm{~N}$ to $4842 \mathrm{~kg} / \mathrm{ha}$ with $120 \mathrm{kgN} / \mathrm{ha}$, suggesting that nitrogen fertilizer application is cardinal to increasing upland rice yields in Uganda. Grain yields continued to be linear at incremental rates of $\mathrm{N}$ fertilizer, suggesting that the present recommendation of 50 $\mathrm{kgN} / \mathrm{ha}$ is insufficient for optimal upland rice productivity. In addition, the highest grain yields obtained at 120 $\mathrm{kgN} / \mathrm{ha}$ compared to $40 \mathrm{kgN} / \mathrm{ha}$ showed that application of the latter is inadequate for optimum grain yield output. Conversely, there was no significant difference in grain yield between $80 \mathrm{kgN} / \mathrm{ha}$ and $120 \mathrm{kgN} / \mathrm{ha}$ in Masindi and Luweero, suggesting that the high organic matter content in the two locations significantly 
contributed to the high response to nitrogen fertilizer application at $80 \mathrm{kgN} / \mathrm{ha}$. Linquist and Sengxua, 2001 reported an increase in indigenous nitrogen supply by almost $10 \mathrm{~kg} / \mathrm{ha}$ and yield by $0.77 \mathrm{t} / \mathrm{ha}$ when adequate soil organic matter is available, confirming the importance of organic matter in complementing inorganic fertilizer application in upland rice cultivation. NERICA 4 significantly outperformed other cultivars in 2009 , when there was relatively less moisture (data not shown), suggesting that NERICA 4 is more efficient in N utilization under water limited conditions than other varieties. Increase in grain yields of NERICA 4 is not a deviation of genotypic differences in relation to varietal characteristics. This cultivar consistently produced higher yields even under no fertilizer suggesting genotypic based response vis-à-vis grain yield increase due to $\mathrm{N}$ fertilizer application. These observations are similar to those of Pinheiro and de Castro (2000), in which upland rice yields of $>5 \mathrm{t} / \mathrm{ha}$ with improved varieties have been reported in Brazil, and northern China (Wang et al., 2002). Tiller and panicle number were significantly increased in all cultivars at $120 \mathrm{kgN} / \mathrm{ha}$, and the trend was linearly related to grain yield. Studies by Yoshida et al., (1972) indicate that as the amount of nitrogen absorbed by the rice crop increases, there is an increase in the number of tillers and panicles per square meter. Across locations, NERICA 4 and NARIC 2 produced the highest number of tillers and panicles $/ \mathrm{m}^{2}$ suggesting that the two varieties are probably more efficient in nitrogen utilization than NARIC 1 and NERICA 1. However, the higher percentage increase in the number of tillers compared with the increase in the number of panicles suggests that there was a wasteful production of tillers. NERICA 1 was previously found to absorb greater amounts of $\mathrm{N}$ than the Japanese cultivars, a trait which is thought, probably, to contribute to the greater biomass production and sink formation in the NERICAs (Matsunami et al., 2009). Conversely, NERICA 4 (a new ecotype) and NARIC 2 (Oryza sativa) both outperformed NERICA 1 suggesting that nitrogen use efficiency coupled with genetic potential contributed to their high productivity over NERICA 1 . NERICA 4 also produced the highest number of grains per panicle when compared to the other varieties. Previous studies have shown that rice plants generally differentiate excess spikelets depending on the nitrogen uptake ability (Horie et al., 1997), some varieties being efficient in this aspect than others. NARIC 2 recorded a significantly higher 1000 grain weight than the rest of the cultivars tested. The heavier grains relate to sink capacity and efficiency of assimilate partitioning to the grains thus contributing to the high grain yield. Among the yield components, tillers $\mathrm{m}^{-2}$ and panicles $\mathrm{m}^{-2}$ had highest correlations with grain yield ( $\mathrm{r}=0.90$ for both traits) (Table 7). Earlier studies also reveal a consistently close relationship between grain yield and yield components with nitrogen fertilization (De Datta, 1989; Kirrilov and Pavlov, 1989; Indira, 2005). This association is influenced by availability of nitrogen at critical stages of growth thus contributing to increased productivity. However, plant nitrogen utilization is associated with increased demand for P and K (Rajput et al., 1988; Dobermann and Fairhurst, 2000). This study did not consider varying P and K as it is reported elsewhere (De Datta, 1989; Dobermann and Fairhurst, 2000; Aulakh and Malhi, 2004; Goulding et al., 2007). This is the first study to detect variety differences in the upland rice yield response to nitrogen fertilizer application under Ugandan upland rice agro-ecological conditions. Further research on evaluating and mapping nitrogen-supplying power of soils in the various cropping systems in the country is needed for area or agro-ecology specific technology package recommendations. The significant interaction of location $\mathrm{x}$ fertilizer and location $\mathrm{x}$ variety attests to this need.

\section{Conclusion}

The current $\mathrm{N}$ recommendation for improved upland varieties in Uganda is $50 \mathrm{kgN} / \mathrm{ha}$. This recommendation is based on economic aspects rather than experimental data. Thus, it hides the potential associated with $\mathrm{N}$ application. The present study showed that grain yield and yield components responded positively to increasing rates of nitrogen fertilization. Based on the data, $80 \mathrm{kgN} / \mathrm{ha}$ or $120 \mathrm{kgN} / \mathrm{ha}$ is appropriate recommendation to realize optimum rice yields. In all the study areas, NERICA 4 and NARIC 2 outperformed NERICA 1 and NARIC 1, and yield trends were consistent over the years suggesting that the two cultivars are productive under high nitrogen doses. However, the productivity gains are probably related to genetic potential of the varieties rather than the $\mathrm{N}$ fertilizer effect, as reflected by the consistent relative performance between $0 \mathrm{~N}$ and other $\mathrm{N}$ rates. The current rate of $120 \mathrm{kgN} / \mathrm{ha}$ also points to the fact that there is decreased soil fertility because of continuous soil mining due to limited land and limited fertilizer use.

\section{Acknowledgement}

This work was funded through a grant from the Rockefeller Foundation to support rice research by the Cereals Research Program based at National Crops Resources Research Institute. The contribution of this institution to this research and increased promotion and production of rice is greatly appreciated. We would like to thank Africa Rice for providing the germplasm and other capacity building efforts. 


\section{References}

Aulakh, M. S., \& Malhi, S. S. (2004). Fertilizer nitrogen use efficiency as influenced by interactions with other nutrients. In Agriculture and the nitrogen cycle. Assessing the impacts of fertilizer use on food production and the environment (eds. A. R. Mosier, J. K. Syers \& J. R. Freney). SCOPE 65, ch. 13, pp. 181-191. Washington, DC: Island Press.

Boling, A. A., Tuong, T. P., Suganda, H., Konboon, Y., Harnpichitvitaya, D., Bouman, B. A. M., \& Franco, D. T. (2008). The effect of toposequence position on soil properties, hydrology, and yield of rainfed lowland rice in Southeast Asia. Field Crops Res., 106, 22-33.

Briggs, \& Twomlow, S. J. (2002). Organic material flows within a smallholder highland farming system of Southwest Uganda. Agriculture. Eco-systems and Environment, 89, 191-212.

Clark, L. J., Gowing, D. J. G., Lark, R. M., Leeds-Harrison, P. B., Miller, A. J., Wells, D. M., Whalley, W. R., \& Whitmore, A. P. (2005). Sensing the physical and nutritional status of the root environment in the field: a review of progress and opportunities. J. Agric. Sci., 143, 347-358. http://dx.doi.org/10.1017/S0021859605005253

Dobermann, A., Witt, C., \& Dawe, D. (2004). Increasing the Productivity of Intensive Rice Systems through Site-Specific Nutrient Management. Enfield, NH (USA) and Los Baños (Philippines): Science Publishers Inc., and International Rice Research Institute (IRRI), 1-420.

Dobermann, A., \& Fairhurst, T. H. (2000). Rice nutrient disorders and nutrient management. In Potash and phosphate institute, Singapore and International Rice Research Institute (IRRI). Los Banos, Philippines, 191.

Goulding, K., Jarvis, S., \& Whitmore, A. (2007). Optimizing nutrient management for farm systems. Phil Trans.R. Soc. B., 363, 667-680.

Haefele, S. M., Jabbar, S. M. A., Siopongco, J. D. L. C., Tirol-Padre, A., Amarante, S. T., Sta Cruz, P. C., \& Cosico, W. C. (2008). Nitrogen use efficiency in selected rice (Oryza sativa L.) genotypes under different water regimes and nitrogen levels. Field Crops Res., 107, 137-146. http://dx.doi.org/10.1016/j.fcr.2008.01.007

Hasegawa, T., Koroda, Y., Seligman, N. G., \& Horie, T. (1994). Response of spikelet number to plant nitrogen concentration and dry weight in paddy rice. Agron. Journal, 86, 673-676.

Horie, T., Ohnishi, M., Angus, J. F., Lewin, L. G., Tsukaguchi, T., \& Matano, T. (1997). Physiological characteristics of high-yielding rice inferred from cross-location experiments. Field Crops Res., 52, 55-67. http://dx.doi.org/10.1016/S0378-4290(96)03458-2

Indira, C. (2005). Effect of nitrogen fertilizer on growth, yield and quality of hybrid rice (Oryza sativa). $J$. Central European Agric., 6, 611-618.

Jones, M. P., Dingkuhn, M., Aluko, G. K., \& Semon, M. (1997). Interspecific Oryza sativa L. X O. glaberrima Steud. progenies in upland rice improvement. Euphytica, 92, 237-246.

Kijima, Y., Keijiro, O., \& Sserunkuuma, D. (2006). Assessing the impact of NERICA on income and poverty in central and western Uganda. FASID Discussion Paper Series on International Development Strategies, No. 2007-10-001.

Kirrilov, Y. A. I., \& Pavlov, V. D. (1989). Effect of fertilizer on yield and protein contents in wheat grain. Agrochimiya, 1, 49-51.

Koutroubas, S. D., \& Ntanos, D. A. (2003). Genotypic differences for grain yield and nitrogen utilization in Indica and Japonica rice under Mediterranean conditions. Field Crops Res., 83, 251-260. http://dx.doi.org/10.1016/S0378-4290(03)00067-4

Ligeng, J., Tingbo, D., Dong, J., Weixing, C., Xiuqin, G., \& Shanqing, W. (2004). Characterizing physiological N-use efficiency as influenced by nitrogen management in three rice cultivars. Field Crops Res., 83, 239-250. http://dx.doi.org/10.1016/j.fcr.2004.01.023

Linquist, B., \& Sengxua, P. (2001). Nutrient management in rainfed lowland rice in the Lao PDR. Los Banos (Philippines): International Rice Research Institute (IRRI), 88.

Matsunami, M., Matsunami, T., \& Kokubun, M. (2009). Growth and Yield of New Rice for Africa (NERICAs) under Different Ecosystems and Nitrogen Levels. Plant Prod. Sci., 12, 381-389.

Odogola, R. W. (2006). Final survey report on the status of rice production, processing and marketing in Uganda. http://www.mofa.go.jp/mofaj/gaiko/oda/bunya/agriculture/pdf/uganda_report.pdf 
Ogenga-Latigo, M. W. (1995). Development of upland rice production in Uganda: Potential, Status and Constraints. First Progress Report to the Rockefeller Foundation, 32.

Peng, S., \& Cassman, K. G. (1998). Upper thresholds of nitrogen uptake rates and associated nitrogen fertilizer efficiencies in irrigated rice. Agron. J., 90, 178-185.

Peng, S., Garcia, F. V., Laza, R. C., Sanico, A. L., Visperas, R. M., \& Cassman, K. G. (1996). Increased N use efficiency using a chlorophyll meter on high-yielding irrigated rice. Field Crops Res., 47, 243-252. http://dx.doi.org/10.1016/0378-4290(96)00018-4

Pinheiro, B., \& de Castro, B. (2000). Upland rice in Brazil: impact of altering plant type and grain appearance. In Aerobic Rice Workshop proceedings. 7-8 September. International Rice Research Institute, Los Baños, Philippines.

Rajput, M. K. K., Ansari, A. H., Mehdi, S., \& Hussain, A. M. (1988). Effect of N and P fertilizers alone and in combination with OM on the growth and yield of Toria. Sarhad. J. Agri. Res., 4, 3-6.

Sheehya, J. E., Dionoraa, M. J. A., Mitchellb, P. L., Penga, S., Cassmanc, K. G., Lemaired, G., \& Williams, R. L. (1998). Critical nitrogen concentrations: implications for high-yielding rice (Oryza sativa L.) cultivars in the tropics. Field Crops Res., 59, 31-41. http://dx.doi.org/10.1016/S0378-4290(98)00105-1

Saito, K., Linquist, B., Atlin, G. N., Phanthaboon, K., Shiraiwa, T., \& Horie, T. (2006). Response of traditional and improved upland rice cultivars to $\mathrm{N}$ and $\mathrm{P}$ fertilizer in northern Laos. Field Crops Res., 96, 216-223.

Wang, Shaohua, Yan, Zhu, Haidong, Jiang, \& Weixing, Cao. (2005). Positional differences in nitrogen and sugar concentrations of upper leaves relate to plant $\mathrm{N}$ status in rice under different $\mathrm{N}$ rates. Field Crops Res., 96, 224-234.

Wang, H., Bouman, B. A. M., Dule, Z., Wang, C., \& Moya, P. F. (2002). Aerobic rice in northern China: opportunities and challenges. In Bouman, B. A. M., Hengsdijk, H., Hardy, B., Bindraban, P. S., Tuong, T. P., Ladha, J. K. (Eds.), Water-Wise Rice Production. Proceedings of the International Workshop on Water Wise Rice Production, 8-11 April. International Rice Research Institute (pp. 143-154), Los Baños, Philippines.

Yoshida, S., Cock, J. H., \& Parao, F. T. (1972). Physiological aspects of high yields. In Rice Breeding (pp. 455-469). International Rice Research Institute, Los Banos, Philippines.

Yoshida, S. (1983). Rice. In Smith, W.H., Banta, S.J. (Eds.), Potential Productivity of Field Crops Under Different Environments. International Rice Research Institute, Los Banos, Phillipines, pp. 103-127.

Zhou, Q., \& Wang, J. (2003). Comparison of upper leaf and lower leaf of rice plants in response to supplemental nitrogen levels. J. Plant Nutr., 26, 607-617. http://dx.doi.org/10.1081/PLN-120017668

Table 1. Soil fertility properties of experimental sites for variety response to nitrogen application in Uganda

\begin{tabular}{lllll}
\hline Soil property & Iganga & Masindi & Luweero & Namulonge \\
\hline $\mathrm{pH}$ & 5.30 & 6.20 & 5.80 & 5.60 \\
Organic matter (\%) & 3.02 & 7.90 & 5.21 & 4.81 \\
Available N (\%) & 0.15 & 0.33 & 0.16 & 0.28 \\
Exchangable P (mg/kg) & 5.03 & 10.14 & 7.27 & 9.37 \\
Exchangable K (me/100g) & 0.39 & 0.51 & 0.37 & 0.39 \\
Sand (textural \%) & 62.0 & 52.0 & 54.0 & 56.0 \\
Clay (textural \%) & 24.0 & 34.0 & 24.0 & 34.0 \\
Silt (textural \%) & 14.0 & 14.0 & 22.0 & 10.0 \\
\hline
\end{tabular}


Table 2. $F$ ratios from the combined analysis of variance for grain yield and yield components for four varieties evaluated under four nitrogen fertilizer rates in two years at four locations in Uganda

\begin{tabular}{lllllllll}
\hline Source of var & d.f. & Grain yield & $1000 \mathrm{Gwt}$ & $\mathrm{G} \mathrm{pan}^{-1}$ & $\mathrm{Pan} \mathrm{m}^{-2}$ & $\mathrm{Till} \mathrm{m}^{-2}$ & $\% \mathrm{G}$ fill & Plant ht. \\
\hline Location (L) & 3 & $1590.34^{* *}$ & $1584.65^{* *}$ & $289.24^{* *}$ & $262.79^{* *}$ & $208.45^{* *}$ & $20.44^{* *}$ & $86.68^{* *}$ \\
Year (Y) & 1 & $805.14^{* *}$ & $1.20 \mathrm{~ns}$ & $119.56^{* *}$ & $156.97^{* *}$ & $143.66^{* *}$ & $0.59 \mathrm{~ns}$ & $17.01^{* *}$ \\
Fertilizer (F) & 3 & $3166.56^{* *}$ & $256.83^{* *}$ & $58.27^{* *}$ & $735.54^{* *}$ & $554.9^{* *}$ & $12.34^{* *}$ & $426.39^{* *}$ \\
Variety (V) & 3 & $192.4^{* *}$ & $31.85^{* *}$ & $5.89^{* *}$ & $37.08^{* *}$ & $35.73^{* *}$ & $2.74 \mathrm{~ns}$ & $141.59^{* *}$ \\
L x F & 9 & $58.68^{* *}$ & $7.05^{* *}$ & $24.38^{* *}$ & $5.63^{* *}$ & $3.39^{* *}$ & $0.44 \mathrm{~ns}$ & $4.91^{* *}$ \\
L x V & 9 & $3.20^{* *}$ & $4.52^{* *}$ & $1.70 \mathrm{~ns}$ & $3.17^{* *}$ & $2.75^{* *}$ & $0.52 \mathrm{~ns}$ & $8.53^{* *}$ \\
L x Y & 3 & $126.9^{* *}$ & $2.61 \mathrm{~ns}$ & $61.01^{* *}$ & $16.14^{* *}$ & $15.71^{* *}$ & $13.53^{* *}$ & $100.63^{* *}$ \\
Y x F & 3 & $19.89^{* *}$ & $1.89 \mathrm{~ns}$ & $7.23^{* *}$ & $6.35^{* *}$ & $3.39^{*}$ & $0.63 \mathrm{~ns}$ & $6.59^{* *}$ \\
Y x V & 3 & $0.39 \mathrm{~ns}$ & $0.29 \mathrm{~ns}$ & $4.41^{* *}$ & $5.94^{* *}$ & $4.12^{* *}$ & $1.55 \mathrm{~ns}$ & $17.01^{* *}$ \\
F x V & 9 & $4.24^{* *}$ & $2.51^{*}$ & $2.02 \mathrm{~ns}$ & $1.70 \mathrm{~ns}$ & $1.8 \mathrm{~ns}$ & $0.30 \mathrm{~ns}$ & $2.20 \mathrm{~ns}$ \\
L x F x V & 27 & $1.74^{*}$ & $1.52 \mathrm{~ns}$ & $1.16 \mathrm{~ns}$ & $1.98^{* *}$ & $1.52 \mathrm{~ns}$ & $0.45 \mathrm{~ns}$ & $2.18^{* *}$ \\
L x Y x F & 9 & $59.26^{* *}$ & $4.77^{* *}$ & $30.91^{* *}$ & $3.63^{* *}$ & $2.33^{*}$ & $0.88 \mathrm{~ns}$ & $9.67^{* *}$ \\
L x Y x V & 9 & $6.31^{* *}$ & $1.28 \mathrm{~ns}$ & $3.54^{* *}$ & $3.36^{* *}$ & $2.95^{* *}$ & $0.17 \mathrm{~ns}$ & $1.91 \mathrm{~ns}$ \\
Y x F x V & 9 & $1.92 \mathrm{~ns}$ & $1.30 \mathrm{~ns}$ & $1.64 \mathrm{~ns}$ & $0.94 \mathrm{~ns}$ & $0.66 \mathrm{~ns}$ & $0.63 \mathrm{~ns}$ & $0.49 \mathrm{~ns}$ \\
L x Y x F x V & 27 & $1.96^{* *}$ & $1.20 \mathrm{~ns}$ & $1.59^{*}$ & $1.29 \mathrm{~ns}$ & $0.83 \mathrm{~ns}$ & $0.45 \mathrm{~ns}$ & $1.60^{*}$ \\
\hline
\end{tabular}

**indicates significance of the $\mathrm{F}$ test at $p=0.01 *$ indicates significance at $p=0.05$ and $\mathrm{V}$, variety, $\mathrm{Y}$, year; $\mathrm{L}$, location; F, fertilizer

Table 3. Grain yield and yield components of four varieties grown under four nitrogen fertilizer rates at four locations in Uganda

\begin{tabular}{|c|c|c|c|c|c|c|c|}
\hline & Grain yield $\left(\mathrm{kg} \mathrm{ha}^{-1}\right)$ & $1000 \mathrm{Gwt}(\mathrm{g})$ & Grain filling (\%) & $\mathrm{Gpan}^{-1}$ & $\operatorname{Pan} \mathrm{m}^{-2}$ & Till $\mathrm{m}^{-2}$ & Plant ht. (cm) \\
\hline \multicolumn{8}{|l|}{ Location } \\
\hline Namulonge & $3642 \mathrm{~b}$ & $24.68 \mathrm{a}$ & $0.91 \mathrm{~b}$ & $100.1 \mathrm{~b}$ & $231.4 \mathrm{c}$ & $248.2 \mathrm{c}$ & $97.05 \mathrm{~b}$ \\
\hline Luweero & $4090 \mathrm{c}$ & $31.13 \mathrm{~d}$ & $0.85 \mathrm{a}$ & $117.6 \mathrm{~d}$ & $240.5 \mathrm{~d}$ & $257.6 \mathrm{~d}$ & $99.25 \mathrm{c}$ \\
\hline Iganga & 2449 a & $25.64 \mathrm{~b}$ & $0.91 \mathrm{~b}$ & 79.8 a & $188.1 \mathrm{a}$ & $200.5 \mathrm{a}$ & $91.69 \mathrm{a}$ \\
\hline Masindi & $4522 \mathrm{~d}$ & $30.20 \mathrm{c}$ & $0.91 \mathrm{~b}$ & $105.5 \mathrm{c}$ & $218.4 \mathrm{~b}$ & $232.4 \mathrm{~b}$ & $97.10 \mathrm{~b}$ \\
\hline \multicolumn{8}{|l|}{$\mathrm{N}$ fertilizer (kgN/ha) } \\
\hline 0 & 2411 a & $25.70 \mathrm{a}$ & $0.87 \mathrm{a}$ & 90.9 a & $177.4 \mathrm{a}$ & $190.0 \mathrm{a}$ & $85.21 \mathrm{a}$ \\
\hline 40 & $3292 \mathrm{~b}$ & $27.26 \mathrm{~b}$ & $0.89 \mathrm{ab}$ & $96.4 \mathrm{~b}$ & $213.4 \mathrm{~b}$ & $226.6 \mathrm{~b}$ & $91.80 \mathrm{~b}$ \\
\hline 80 & $4158 \mathrm{c}$ & $28.69 \mathrm{c}$ & $0.90 \mathrm{bc}$ & $106.7 \mathrm{c}$ & $232.4 \mathrm{c}$ & $247.9 \mathrm{c}$ & $101.6 \mathrm{c}$ \\
\hline 120 & $4842 \mathrm{~d}$ & $29.99 \mathrm{~d}$ & $0.92 \mathrm{c}$ & $109.0 \mathrm{c}$ & $255.2 \mathrm{~d}$ & $274.0 \mathrm{~d}$ & $106.5 \mathrm{~d}$ \\
\hline$\%$ increase & 50.5 & 14.30 & 5.43 & 16.6 & 30.5 & 30.7 & 20.0 \\
\hline \multicolumn{8}{|l|}{ Variety } \\
\hline NERICA 1 & $3375 \mathrm{a}$ & $27.47 \mathrm{a}$ & $0.88 \mathrm{a}$ & 97.7 a & $211.2 \mathrm{a}$ & $225.7 \mathrm{a}$ & $90.71 \mathrm{a}$ \\
\hline NERICA 4 & $3904 \mathrm{c}$ & $27.89 \mathrm{~b}$ & $0.90 \mathrm{~b}$ & $103.4 \mathrm{~b}$ & $228.2 \mathrm{~b}$ & $243.8 \mathrm{~b}$ & $99.39 \mathrm{c}$ \\
\hline NARIC 2 & $3881 \mathrm{c}$ & $28.38 \mathrm{c}$ & $0.90 \mathrm{~b}$ & $101.5 \mathrm{~b}$ & $226.6 \mathrm{~b}$ & $240.1 \mathrm{~b}$ & $100.5 \mathrm{~d}$ \\
\hline NARIC 1 & $3543 \mathrm{~b}$ & $27.90 \mathrm{~b}$ & $0.89 \mathrm{ab}$ & $100.4 \mathrm{ab}$ & $212.5 \mathrm{a}$ & $229.0 \mathrm{a}$ & $94.47 \mathrm{~b}$ \\
\hline $\mathrm{LSD}_{0.05}$ (loc main effect) & 62.40 & 0.23 & 0.02 & 2.59 & 3.94 & 4.83 & 0.96 \\
\hline $\mathrm{LSD}_{0.05}$ (Fert main effect) & 64.90 & 0.40 & 0.02 & 3.87 & 4.20 & 5.21 & 1.61 \\
\hline $\mathrm{LSD}_{0.05}$ (Var main effect) & 54.60 & 0.19 & 0.01 & 2.85 & 4.33 & 4.24 & 1.12 \\
\hline
\end{tabular}

Within columns, means followed by the same letters are not significantly different at $5 \%$ probability error 
Table 4. Grain yield at 4 fertilizer treatments averaged over 4 varieties and that of 4 varieties averaged over 4 fertilizer treatments at four locations in Uganda

\begin{tabular}{lllll}
\hline & \multicolumn{4}{c}{ Grain yield $\left(\mathrm{kg} \mathrm{ha}^{-1}\right)$} \\
\cline { 2 - 5 } Locations & Namulonge & Luweero & Iganga & Masindi \\
\hline Fert (KgN/ha) & & & & \\
0 & 2502 & 2420 & 1742 & 2980 \\
40 & 3220 & 3551 & 2057 & 4339 \\
80 & 4148 & 4857 & 2464 & 5162 \\
120 & 4697 & 5530 & 3532 & 5606 \\
Variety & & & & \\
NERICA 1 & 3352 & 3692 & 2267 & 4188 \\
NERICA 4 & 3901 & 4329 & 2676 & 4708 \\
NARIC 2 & 3876 & 4329 & 2624 & 4696 \\
NARIC 1 & 3439 & 4008 & 2229 & 4496 \\
\hline Location means & 3642 & 4090 & 2449 & 4522 \\
LSD $_{0.05}$ (L x F) & & & & 112.3 \\
LSD $_{0.05}$ (L x V) & & & & 226.1 \\
\hline
\end{tabular}

Table 5. Grain yields of the 4 varieties averaged over 4 fertilizer treatments in two years

\begin{tabular}{lllll}
\hline N fertilizer (kgN/ha) & \multicolumn{4}{c}{ Grain yields (kg/ha) } \\
\cline { 2 - 5 }$\underline{\text { Year 2009 (Mar-July) }}$ & NERICA 1 & NERICA 4 & NARIC 2 & NARIC 1 \\
\hline 0 & 1921 & 2317 & 2422 & 2023 \\
40 & 2784 & 3253 & 3087 & 2902 \\
80 & 3375 & 3844 & 3899 & 3655 \\
120 & 4230 & 4887 & 4816 & 4308 \\
$\underline{\text { Year 2008 (Aug-Nov) }}$ & & & & \\
0 & 2311 & 2901 & 2755 & 2639 \\
40 & 3281 & 3711 & 3823 & 3493 \\
80 & 4389 & 4802 & 4862 & 4435 \\
120 & 4708 & 5512 & 5384 & 4887 \\
\hline LSD (Year main effect) & & & & 44.1 \\
LSD (Y x V) & & & & 81.8 \\
LSD (Y x F) & & & & 84.0 \\
\hline
\end{tabular}

Table 6. Mean grain yield of four varieties under four fertilizer treatments for four locations in Uganda

\begin{tabular}{|c|c|c|c|c|}
\hline \multirow[b]{2}{*}{ Variety } & \multicolumn{4}{|c|}{ Grain yield (kg/ha) } \\
\hline & $0 \mathrm{~N}$ & $40 \mathrm{~N}$ & $80 \mathrm{~N}$ & $120 \mathrm{~N}$ \\
\hline NERICA 1 & 2116 & 3032 & 3882 & 4469 \\
\hline NERECA 4 & 2609 & 3482 & 4323 & 5200 \\
\hline NARIC 2 & 2588 & 3455 & 4381 & 5100 \\
\hline NARIC 1 & 2331 & 3198 & 4045 & 4598 \\
\hline Mean & 2411 & 3291.7 & 4157.8 & 4841.8 \\
\hline \multicolumn{4}{|c|}{$\mathrm{LSD}_{0.05}(\mathrm{~F} \times \mathrm{V}$ interraction $)$} & 108.2 \\
\hline
\end{tabular}

Table 7. Correlation of grain yield and yield components across locations, nitrogen fertilizer and varieties

\begin{tabular}{lrrrrrr}
\hline & Grain yield $\left(\mathrm{kg} \mathrm{ha}^{-1}\right)$ & 1000 Gwt $(\mathrm{g})$ & Grain filling (\%) & Gpan $^{-1}$ & Pan m & Till m$^{-2}$ \\
\hline Grain yield $\left(\mathrm{kg} \mathrm{ha}^{-1}\right)$ & 1 & & & & & \\
1000 Gwt $(\mathrm{g})$ & 0.78 & 1 & & & & \\
Grain fill $(\%)$ & 0.30 & -0.16 & 1 & & & \\
Gpan $^{-1}$ & 0.85 & 0.80 & -0.22 & 1 & & \\
Pan m $^{-2}$ & 0.90 & 0.62 & 0.22 & 0.84 & 1 & \\
Till m $^{-2}$ & 0.90 & 0.61 & 0.21 & 0.84 & 1.00 & 1 \\
\hline
\end{tabular}



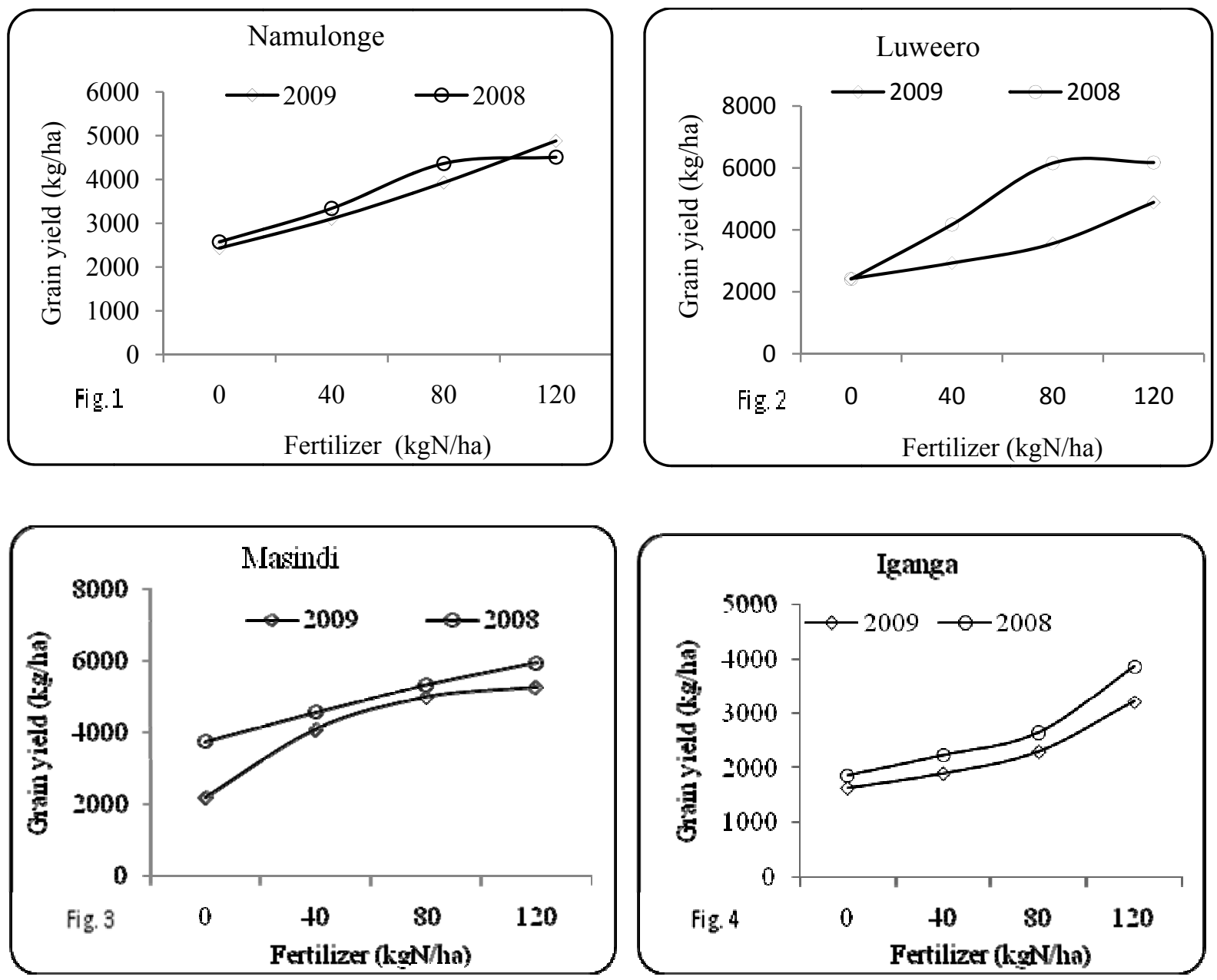

Figure 1-4. Grain yield increase in 2 years averaged over 4 fertilizer rates at different locations in Uganda

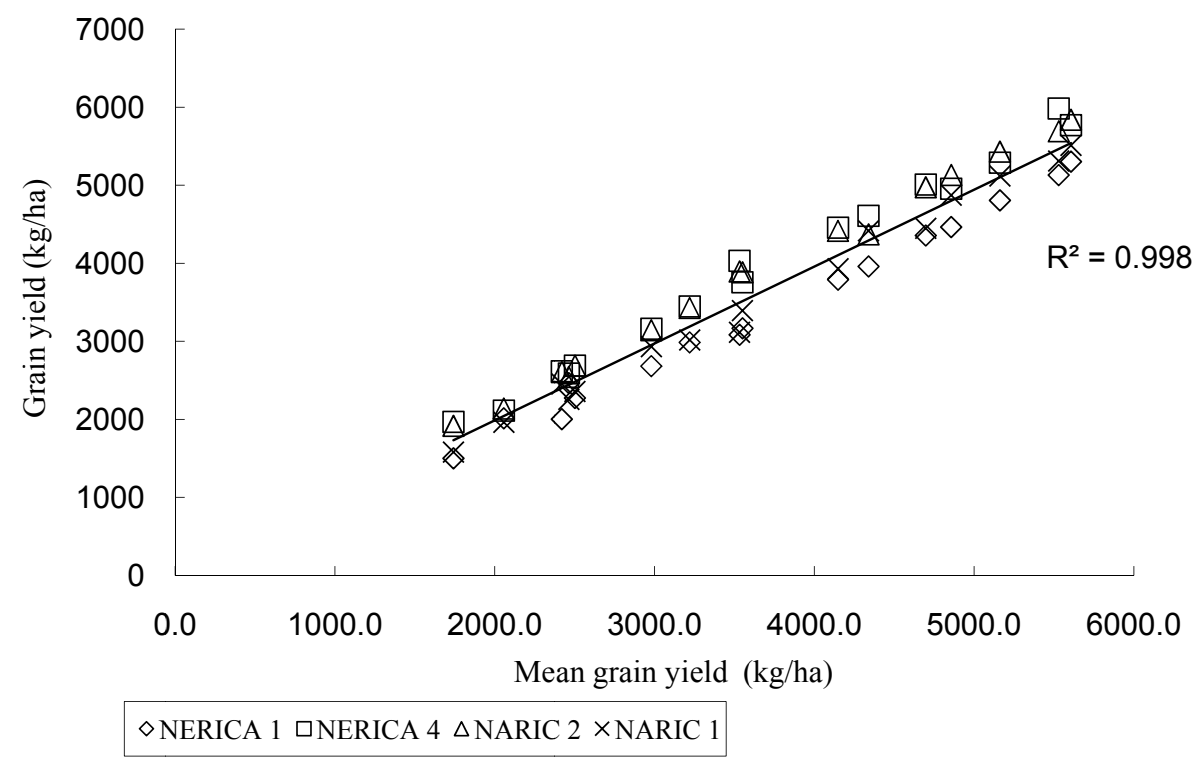

Figure 5. Relationship between mean grain yield of four varieties and grain yield of each variety in 16 environments (four locations by four $\mathrm{N}$ fertilizer treatments) 